\title{
Productive Cough
}

National Cancer Institute

\section{Source}

National Cancer Institute. Productive Cough. NCI Thesaurus. Code C78569.

A cough accompanied by expectorated secretions. 